\title{
Distance Learning In Primary Schools During The Covid-19 Pandemic In Indonesia: Challenges, Solutions, And Projections
}

\author{
${ }^{1}$ Cipta Pramana, ${ }^{2}$ Ratna Susanti, ${ }^{3}$ Kholis Ernawati, ${ }^{4}$ I Putu Ayub Darmawan, ${ }^{5}$ M. Zaini Miftah, ${ }^{6}$ Jamila \\ Lestyowati, ${ }^{7}$ Rini Werdiningsih, ${ }^{8}$ Rahmi Ramadhani
}

\author{
${ }^{1}$ Medical Faculty, Tarumanagara University, Jakarta, Indonesia \\ ${ }^{2}$ Polytechnic Indonusa Surakarta, Indonesia \\ ${ }^{3}$ Faculty of Medicine, Universitas YARSI, Jakarta, Indonesia \\ ${ }^{4}$ Sekolah Tinggi Teologi Simpson Ungaran, Indonesia \\ ${ }^{5}$ Faculty of Teacher Training and Education, Institut Agama Islam Negeri Palangka Raya, Palangka Raya, Indonesia \\ ${ }^{6}$ Financial Education and Training Agency, Yogyakarta, Indonesia \\ ${ }^{7}$ Faculty of Social and Political Sciences, University of 17 August Semarang, Indonesia \\ ${ }^{8}$ Universitas Potensi Utama, Medan, Indonesia
}

Article History: Received:11 January 2021; Accepted: 27 February 2021; Published online: 5 April 2021

ABSTRACT: This study aims to investigate online learning for elementary school students in Indonesia due to the COVID-19 pandemic. The data were collected using a survey method through distributing questionnaires with a google form. Secondary data was also supported using the library method through documentation to gain the relevant data regarding the impact of COVID-19 and online learning in elementary schools from various sources such as documents, books, magazine news, and journal articles. Data analysis used a flow chart following Milles and Huberman. Results show that the impact of COVID-19 on implementing online learning in elementary schools in Indonesia can be implemented quite well. The impact of COVID-19 on the implementation of distance learning in elementary schools can be carried out quite well if there is a collaboration between teachers, students, and parents in learning at home.

Keywords: distance learning; the impact of COVID-19; Indonesian primary schools; online learning

\section{INTRODUCTION}

The COVID-19 virus affects the whole population in Indonesia today. The COVID-19 virus has affected various areas such as social, economic, tourism, and education, according to Kompas, 28/03/2020. On March 18, 2020, as a result of the corona, all indoor and outdoor activities were suspended, particularly in education. Following that, the Republic of Indonesia's Minister of Education and Culture released Circular Letter No. 4 of 2020 on Education Policy Implementation in the Emergency Period of COVID Spread. According to the Circular, the learning process is carried out at home by online/distance learning to provide realistic learning opportunities for students (Ministry of Education and Culture, 2020).

Primary school students should participate in online/distance learning under the supervision of their parents. The use of the internet network in the learning process is known as online learning. Online learning allows students to have more flexibility in their learning schedules, allowing them to learn whenever and wherever they choose (Nuraini et al., 2020). Students and teachers can connect using apps like a classroom, video conferencing, phone or live chat, zoom, meets, or a Whatsapp party (Lapitan et al., 2021). This research is an innovative attempt to address problems by providing a variety of learning opportunities. The learners' characteristics determine the success of a model or learning medium. According to Nakayama, all of the learning literature suggests that not all students will be successful in online learning. This is attributed to factors such as the learning environment and learner characteristics (Nakayama et al., 2007).

An online browser that takes advantage of the internet network's usability, connectivity, versatility, and ability to facilitate various types of learning experiences. Zhang et al. (2004) discovered that using the internet and multimedia tools could bypass studying the old-delivery methods. Online learning uses the internet to put teachers and students together to engage in learning experiences (Kuntarto, 2017). At the implementation level, online learning necessitates the use of mobile devices such as smartphones or Android phones, laptops, computers, tablets, and iPhones that can access information at any time and from any location (Gikas \& Grant, 2013).

The use of mobile technology in educational institutions, including distance learning targets, has substantially contributed (Korucu \& Alkan, 2011). Online courses using Google Classroom, Edmodo, and Schoology services (Iftakhar, 2016), as well as instant messaging applications like WhatsApp, can all help with the introduction of online learning (So, 2016). Even social media platforms like Facebook and Instagram can be used to learn online (Nanda, 2019). Students can communicate, interact, and collaborate directly and indirectly with their learning tools (databases, experts/instructors, libraries) that are physically different or even distant. Distance learning that uses telecommunications and information technology, such as the internet and CD-ROOM, is known as online learning (Smaldino, 2012).

Several volunteer technology companies help promote national education by ensuring that students impacted by COVID-19 can pursue their studies. In a statement released on March 15, 2020, the Minister of National Education of the Republic of Indonesia confirmed that funding from many technology companies was publicly available and 
accessible and that each platform provided students with the opportunity to learn online. Rumah Belajar, a self-learning portal run by the Ministry of National Education, has a website for students. Room-teachers have also announced the launch of the Free Teacher-Room Online School. Students will participate in online distance learning (live teaching) via this program from Monday to Friday, much as they would at school. Sekolah.mu, which partners with hundreds of schools and organizations, has organized classroom and career learning for all students, teachers, and even parents.

The online learning network in Indonesia during the COVID-19 Pandemic can be seen in Table 1, based on the investigation findings.

\section{Table 1. Online learning network in Indonesia during the COVID-19 pandemic}

\begin{tabular}{lll}
\hline No. & Platform Name & Access Page \\
\hline 1 & Learning House & https://belajar.kemdikbud.go.id \\
2 & Smart Class & https://kelaspintar.id \\
3 & Ruangguru Online School & https://ruangguru.onelink.me \\
4 & Quipper School & https://quipper.com/id/school/teachers/ \\
5 & Your school & https://www.sekolah.mu/tanpabatas \\
6 & Zenius & https://zenius.net/belajar-mandiri \\
7 & Microsoft Office 365 & https://microsoft.com/en-id/education/products/office \\
8 & Google G Suite for Education & https://blog.google/outreach-initiatives/education \\
\hline
\end{tabular}

\section{Relevant Previous Research}

According to Putri et al. (2020) the impact of COVID-19 on the online learning process in elementary schools has an impact on students, parents, and teachers themselves. Some of the impacts that students feel are that students are not familiar with the way of distance learning because previously the learning was carried out through face-to-face. Students have become accustomed to being at school, interacting, playing, joking with their friends and coming face-to-face with their teachers.

Distance learning has made students need time to adapt and face new habits that will indirectly affect their learning abilities. For parents, distance learning incurs additional costs such as purchasing internet quota and requires a network connection to the internet. Teachers also feel the impact of distance learning. Teachers, especially senior teachers are less adept at using online technology or social media as a means of learning. They need mentoring and training in advance in order to be able to operate a variety of remote learning devices. Support and cooperation from parents is needed for the success of learning. Communication between teachers and schools and parents must also be established smoothly (Putri et al., 2020).

\section{METHOD}

This research applied a survey research design. Data collection was carried out through a survey to obtain information in an online questionnaire using the Google Form application related to online learning carried out in elementary schools during the COVID-19 Pandemic. The sampling technique was purposive sampling. The sample in this study was 227 elementary school teachers throughout Indonesia. Questions about the implementation of online learning, the platform used, the obstacles faced, and solutions to these obstacles. The data regarding the survey results were analyzed using descriptive and qualitative analysis techniques. Describe the characteristics of age, education, years of service, school origin based on districts/provinces. Find out if we have received online learning training. They knew whether we have ever carried out online learning. It also describes the online learning platform used, online learning schedules, obstacles during online learning, alternative problem-solving during learning, and support for facilities and infrastructure.

Analysis of the research data was carried out using the analysis model of Miles \& Huberman (1994), which consists of three stages, namely data reduction, data display, and conclusion drawing and verification. Analysis of research data, the data reduction stage is the stage of collecting all the information needed from the interview results and then grouping the data. The data display stage is the exposure of data needed in research, which does not need to be discarded. The withdrawal and conclusion verification stage is the stage of interpreting research data to draw conclusions based on the phenomena obtained (Miles \& Huberman, 1994).

\section{RESULT}

The research was conducted from July 19, 2020, to July 24, 2020, with a sample of 220 elementary school teachers spread across 30 districts/cities from 16 provinces in Indonesia with the characteristics shown in Table 2.

Table 2. Distribution of respondent characteristics $(n=220)$

\begin{tabular}{lll}
\hline Characteristics & Frequency & $\%$ \\
\hline Age & & \\
$<30$ years & 49 & 22.3 \\
$30-40$ years & 81 & 36.8 \\
\hline
\end{tabular}


${ }^{1}$ Cipta Pramana, ${ }^{2}$ Ratna Susanti, ${ }^{3}$ Kholis Ernawati, ${ }^{4}$ Putu Ayub Darmawan, ${ }^{5}$ M. Zaini Miftah, ${ }^{6}$ Jamila Lestyowati, ${ }^{7}$ Rini Werdiningsih, ${ }^{8}$ Rahmi Ramadhani

\begin{tabular}{|c|c|c|}
\hline 41-50 years & 39 & 17.7 \\
\hline$>50$ years & 51 & \\
\hline \multicolumn{3}{|l|}{ Education } \\
\hline Diploma & 5 & 2.3 \\
\hline S1 & 191 & 86.8 \\
\hline S2 & 24 & 10.9 \\
\hline \multicolumn{3}{|l|}{ Years of service } \\
\hline$<5$ years & 53 & 24.1 \\
\hline $5-10$ years & 42 & 19.1 \\
\hline$>10$ years & 125 & 56.8 \\
\hline \multicolumn{3}{|l|}{ Origin of schools by province } \\
\hline Bali & 2 & .9 \\
\hline Bengkulu & 1 & .5 \\
\hline Special Region of Yogyakarta & 4 & 1.8 \\
\hline DKI Jakarta & 1 & .5 \\
\hline West Java & 1 & .5 \\
\hline Central Java & 134 & 61.2 \\
\hline East Java & 23 & 10.5 \\
\hline West Kalimantan & 2 & .9 \\
\hline South Borneo & 1 & .5 \\
\hline Central Kalimantan & 13 & 5.9 \\
\hline North Kalimantan & 1 & .5 \\
\hline Lampung & 1 & .5 \\
\hline Maluku & 1 & .5 \\
\hline Riau & 1 & .5 \\
\hline Southeast Sulawesi & 1 & .5 \\
\hline North Sulawesi & 32 & 14.6 \\
\hline
\end{tabular}

Table 2 shows that the respondents tend to be 30-40 years old, predominantly have an undergraduate degree with a work period of $>10$ years. Most elementary school teachers come from elementary schools in Central Java province.

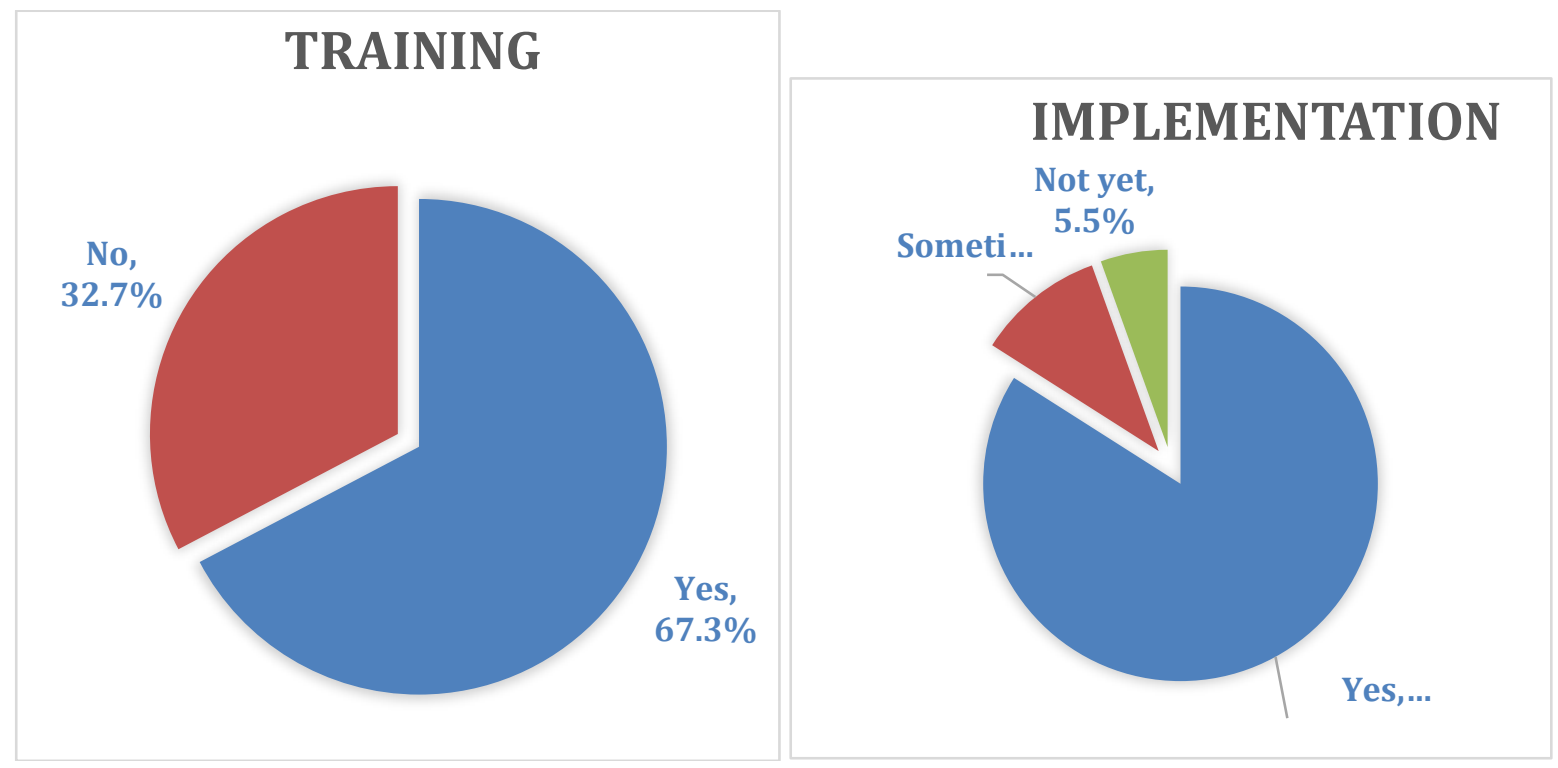

Figure 1. Online Learning Training

Figure 2. Online Learning Implementation

Before implementing online learning, the majority of elementary school teachers had received training on online learning, namely $67.3 \%$, and there were still $32.7 \%$ of elementary school teachers who had never attended online learning training (Figure 1). Even so, there are $84.1 \%$ of elementary school teachers have implemented online learning (Figure 2). 
Distance Learning In Primary Schools During The Covid-19 Pandemic In Indonesia: Challenges, Solutions, And Projections

To see the relationship between the implementation of online learning and online learning training, data is presented in Table 3 .

Table 3. The relationship between the implementation of online learning and online learning training.

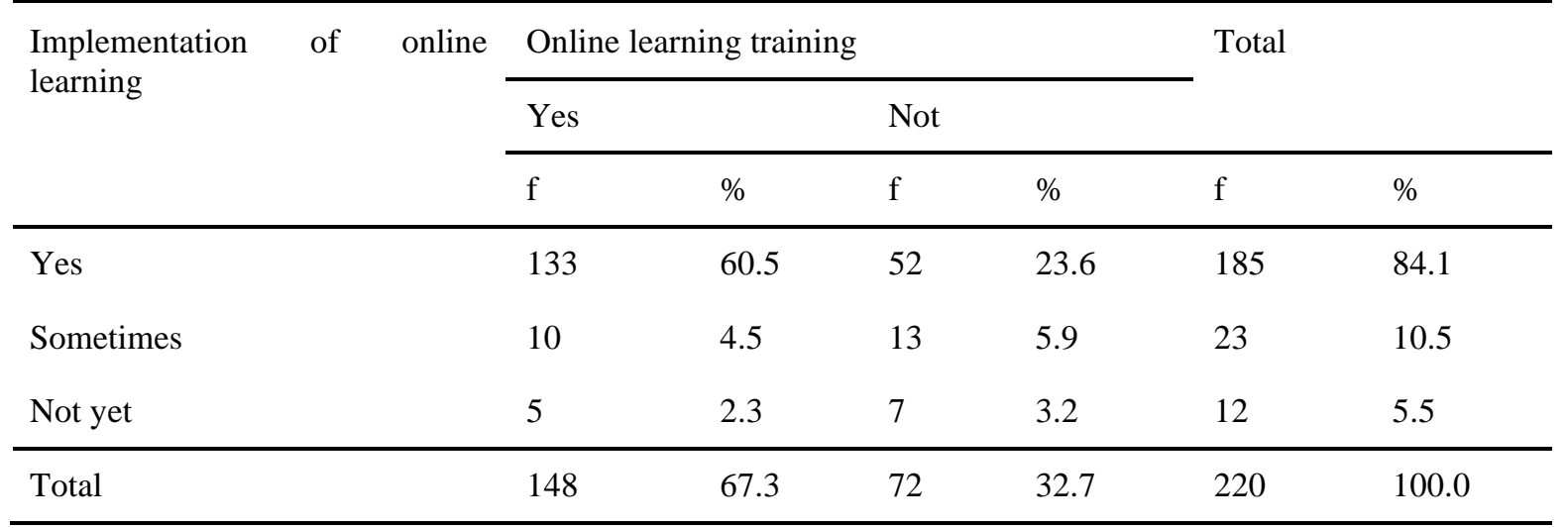

The data in Table 3 shows that most elementary school teachers who carry out online learning have received online learning training, namely $60.5 \%$, and elementary school teachers who carry out online learning, even though they have not received training $(23.6 \%)$.

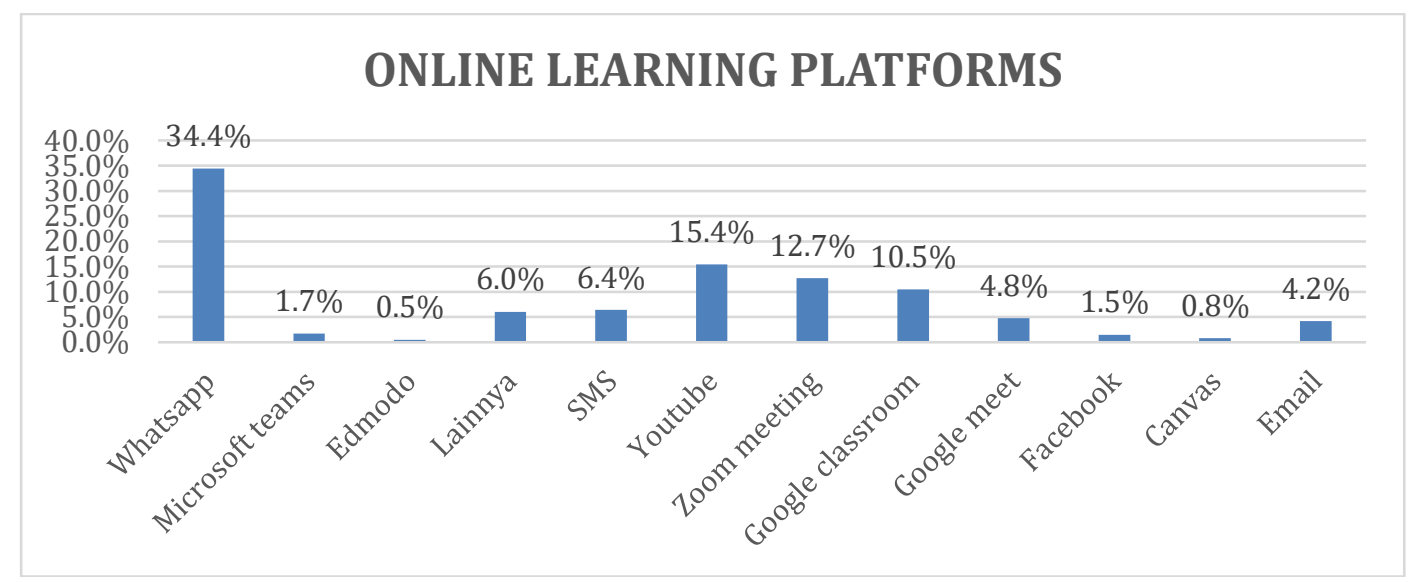

Figure 3. The platform used in online learning

Figure 3 shows the various platforms commonly used by elementary school teachers in online learning and the most using the WhatsApp application (34.4\%). There are also $15.4 \%$ of elementary school teachers who use YouTube as a medium of learning; there is also $12.7 \%$ who use zoom meetings.

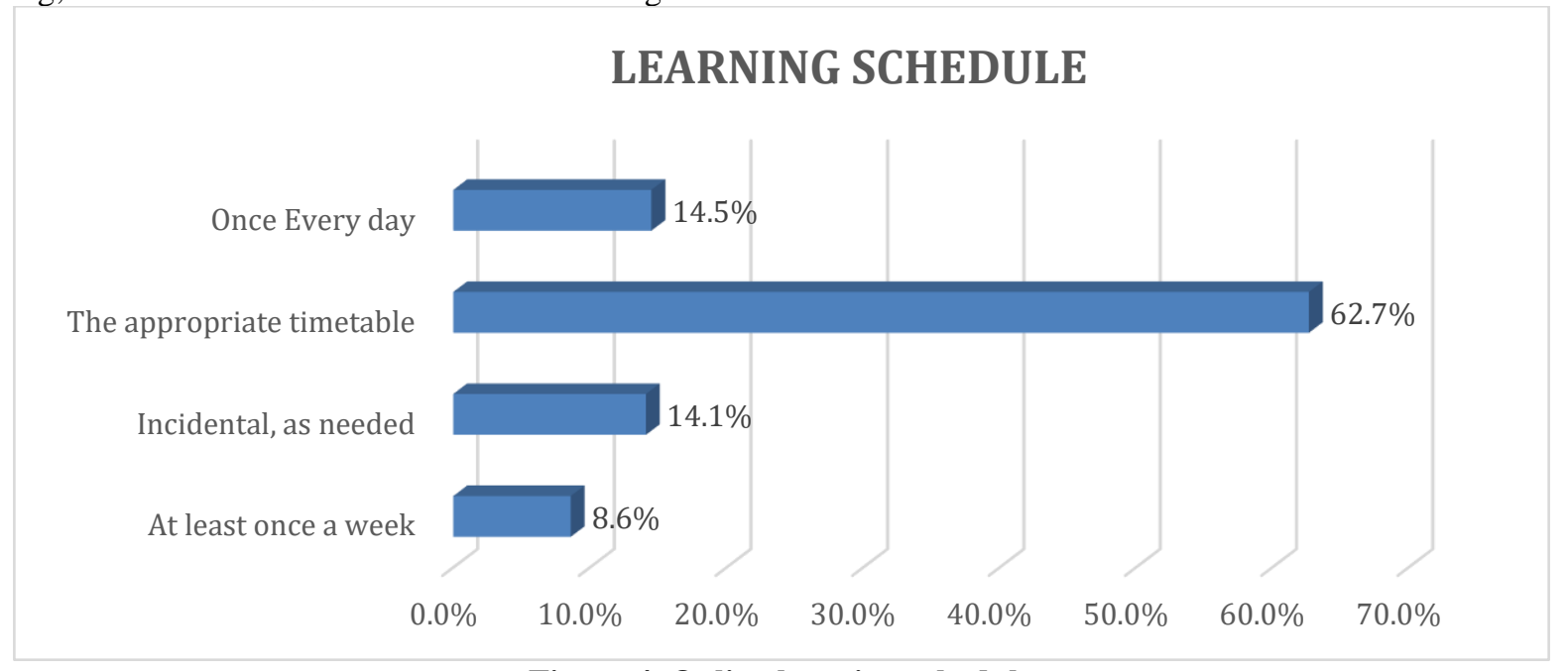

Figure 4. Online learning schedule 
Based on the data in Figure 4, most elementary school teachers carry out online learning according to the lesson schedule $(62.7 \%)$, and only $8.6 \%$ carry out learning a minimum of once a week.

Almost all (95.9\%) elementary school teachers experience obstacles during online learning. Respondents' answers related to obstacles during online learning were checked using the Nvivo $12+$ word frequency. Obtained the highest keyword from the respondent's answer is "handphone" as 110 words, "network" as 73 words, "quota" as many as 59 words which can be seen in full in Figure 5.

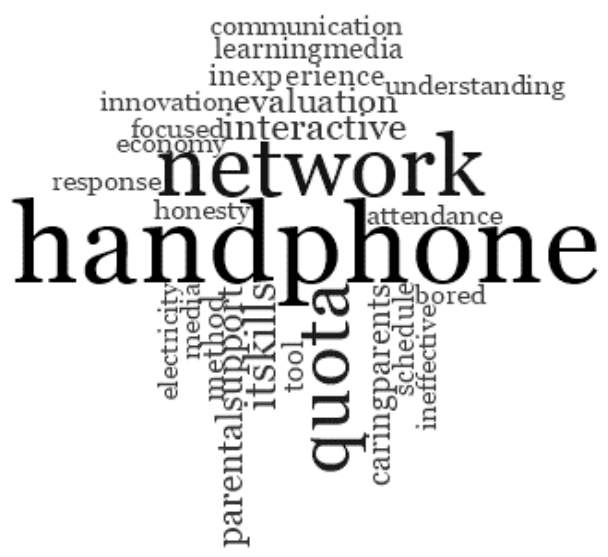

Figure 5. The most common obstacles found

Based on qualitative data, the respondents' answers related to the obstacles felt during online learning are summarized in Table 4.

Table 4. Barriers that teachers feel during online learning

\begin{tabular}{ll}
\hline Category & Barrier description \\
\hline Teacher & $\begin{array}{l}\text { Information Communication Technology's ability is low, lack of experience, low } \\
\text { interaction, learning media, learning methods, attendance, and evaluation. }\end{array}$
\end{tabular}

Parents

Lack of parental support, low information and communication technology skills, and lack of parental care help students study at home.

Students Lack of ability to operate learning applications, easily bored.

System Lack of infrastructure in the form of internet/wifi network, weak signal/cellphone network, lack of electronic devices such as smartphones.

Economy

Data package prices that are less affordable, the inability to buy cellphones for children.

Table 5 shows that elementary school teachers get internet access (data packages) from schools (35.9\%), although there are still $24.5 \%$ of elementary school teachers who provide internet access (data packages) themselves for online learning. On the other hand, there are still a few schools that provide eLearning media to support online learning (7.7\%). When viewed from the support of online learning training, most of the primary school teachers received training on their initiative $(16.6 \%)$, only $10.3 \%$ of elementary school teachers received training from schools. 
Distance Learning In Primary Schools During The Covid-19 Pandemic In Indonesia: Challenges, Solutions, And Projections

Table 5. Support for facilities and infrastructure during online learning $(\mathbf{n}=\mathbf{2 2 0})$

\begin{tabular}{|c|c|c|}
\hline Facilities and infrastructure & Frequency & $\%$ \\
\hline The existence of eLearning media provided by schools & 36 & 7.7 \\
\hline There are exceptional trainers from schools for online learning training & 48 & 10.3 \\
\hline $\begin{array}{l}\text { Receive online learning training on your initiative (e.g., take part in webinars, } \\
\text { online workshops, etc.) }\end{array}$ & 77 & 16.6 \\
\hline Internet access (data package) provided by the teacher & 114 & 24.5 \\
\hline \multicolumn{3}{|l|}{ The school provides Internet access (data package) } \\
\hline \multicolumn{3}{|l|}{167} \\
\hline \multicolumn{3}{|l|}{35.9} \\
\hline \multicolumn{3}{|l|}{ Other providers provide } \\
\hline Internet access (data package) & 23 & 4.9 \\
\hline
\end{tabular}

\section{DISCUSSION}

The education situation in Indonesia has changed suddenly in March 2020 since the first case of the COVID-19 coronavirus contagion was noticed in Indonesia (Ihsanuddin, 2020; Unicef, 2020). Furthermore, Indonesia may be one of the countries besides Georgia that suspends the education and learning process (Basilaia \& Kvavadze, 2020).

Our study of 220 elementary school teachers spread across 30 districts/cities from 16 provinces in Indonesia shows that the most respondents are 30-40 years old, predominantly have a Bachelor degree, 191 respondents (86.8\%), 24 Postgraduate (10.9\%), and Diploma $5(2.3 \%)$, with a maximum service life of $>10$ years $(5.68 \%)$. Most of the elementary school teachers came from elementary schools in the province of Central Java; there were 134 respondents (61.2\%), North Sulawesi 32 (14.6\%), and East Java 23 (10.5\%). Research by Irfan Fauzi, Iman Hermawan Sastra Khusuma was conducted in Banten and West Java through a survey. Respondents are elementary school teachers. Out of 45 elementary school teachers, there are 17 male teachers and 28 female teachers. The length of teaching for each teacher varies from at least one year to a maximum of 24 years. Among these elementary school teachers, they have a working period between 1-5 years (Fauzi \& Khusuma, 2020).

Before implementing online learning, most elementary school teachers received training on online learning, namely $67.3 \%$. Technology readiness determines the success of online learning in Indonesia during the COVID-19 Pandemic. Technology readiness will smooth out support, access, and collaboration between parents, teachers, schools, communities, and the government to build effective learning methods by the national curriculum. Technology readiness also ensures students follow the learning process. This form of support is the training in the use of technology for teachers, designing and monitoring online learning (Rusmiati et al., 2020).

\section{Distance learning platform}

In our research, the platform commonly used by elementary school teachers in online learning mostly uses the WhatsApp application (34.4\%). There are also $15.4 \%$ of elementary school teachers who use YouTube as a learning medium, and $12.7 \%$ who use zoom meetings. Many other studies have also used the Wahtsapp platform for the learning process at the elementary school level (Dewi, 2020; Purwanto et al., 2020), considering that most students, parents, and teachers have a social media application, namely WhatsApp, on their respective gadgets. Discussions are conducted by students and teachers well; the teacher utilizes WhatsApp's features to distribute the subject matter and assignments to students; then the assignments have been done will be sent by students through this group as well. Teachers monitor and assist students in carrying out assignments. The activity of giving and sending this assignment is done by having parents as the liaison (Lestari \& Gunawan, 2020). There is even a study as many as $100 \%$ use the Whatsapp Group platform in the learning process. This is because people in everyday life often use this application. The WhatsApp application is easy and inexpensive to use, user-friendly, and can write and dispatch messages in real-time (Setiawan \& Iasha, 2020). This statement is also following Ahmad et al., which states that using Whatsapp groups a simple, easy-to-use, inexpensive application in the learning process (Ahmad et al., 2020; Sahidillah \& Miftahurrisqi, 2019). WhatsApp provides answers to students and helps increase learner guidance feelings they always have their college time. This helps simplify arguments in a more streamlined manner and guides learners to overcome their weaknesses using language (Jere et al., 2019).

\section{Barriers to the distance learning process}

Almost all (95.9\%) elementary school teachers feel that there are challenges and obstacles during online learning. The obstacles that were most felt were the "handphone," "internet network," and "quota" problems. Another study conducted by Rusmiati et al. (2020) state that during the online learning process, the challenges teachers face are technical problems, 
including not all parents of students having cellphones or laptops, low signals, especially those who live in the suburbs, and students with families who are economically disadvantaged. These obstacles resulted in some students not attending lessons and delays in completing assignments given by the teacher. A lousy internet network also affects the learning process, so that it is challenging to prepare learning materials online. Apart from these factors, some obstacles interfere with the learning process, namely the availability of data packages. The essential factors in the smoothness of the learning process are the existence of a good internet network, sufficient data packages, and the ownership of a cellphone or laptop for each student (Rusmiati et al., 2020).

Online learning is indeed the primary solution for continuing to carry out learning amid the COVID-19 plague. Besides having a positive impact, online learning has experienced many obstacles experienced by students, teachers, and parents. Most of the teachers stated that the teaching time was reduced, and it was feared that it would impact student achievement. And not even a few teachers do not understand information and communication technology, coupled with an unstable internet connection (Zaharah \& Kirilova, 2020).

Research conducted in Turkey found obstacles during the COVID-19 plague in the process of online learning, inter alia students' inability to access the internet, weak infrastructure, and lack of ability to use communication and information technology. Another problem is about management in the classroom so that students cannot help but follow the subject matter given during the teaching and learning process properly (Sari \& Nayir, 2020).

\section{Troubleshooting solutions}

To overcome various kinds of obstacles, the school institution or the teacher concerned has an innovation so that the learning process's implementation goes well and smoothly. The solution provided is the existence of eLearning media provided by schools, exceptional trainers from schools, the teacher's initiative for online learning, internet access/data packages provided by teachers or schools, or other providers. Regarding the data package, $35.9 \%$ of primary school teachers get it from schools, while about online learning training from schools, only $10.3 \%$, and $16.6 \%$ because of their initiative.

Research in Turkey has several solutions to overcome problems during the online learning process, namely improving classroom management by changing the syllabus, preparing new learning activities, motivating students, and using learning courses with different materials. The way to overcome other obstacles is to ask for help from internet providers, colleagues, family, or experts' assistance (Sari \& Nayir, 2020).

Every institution must be able to provide solutions so that the learning process runs well during a pandemic. Must be able to overcome technical and administrative problems by planning, including discussing the right content so that learning development is not hampered. Online-based learning provides space for teachers to be more active and innovative in communicating with students. Teachers can set time limits and reminders for students so that they continue to concentrate on their learning. Efforts must be maximally acknowledged to achieve the desired learning goals (Nuraini et al., 2020).

\section{CONCLUSION}

WhatsApp is the most used platform during the distance learning process during the COVID-19 Pandemic. This is because many people often use this application in everyday life, easy to use at a low price.

There are still many obstacles and problems in the eLearning learning process during the COVID-19 Pandemic, including the internet connection problems felt by teachers, students, and students' parents. These problems are the lack of the ability of teachers to use information and communication technology, the lack of support and ability of parents to assist students to study at home, the lack of infrastructure for the ownership of mobile phones or laptops by students, and the price of data packages that are not affordable for some students from the group. The economy is weak.

However, efforts to improve were made, among others, some teachers got data packages from schools, some school institutions provided eLearning media to support the teaching and learning process. Also, teachers can use eLearning media properly. Some of the teachers receive special training on the use of technology and information systems.

ACKNOWLEDGMENT: Not applicable.

FUNDING: Not applicable

COMPETING INTEREST: The authors state that they do not have to compete for financial interests or personal relationships that can affect the work reported in this paper.

\section{REFERENCE}

1. Ahmad, S., Zulfikar, T., \& Hardiana, F. (2020). The use of social media whatsapp among English education students for solving thesis writing problems. Humanities and Social Sciences Reviews, 8(3), 447-455. https://doi.org/10.18510/hssr.2020.8348

2. Basilaia, G., \& Kvavadze, D. (2020). Transition to Online Education in Schools during a SARS-CoV-2 Coronavirus (COVID-19) Pandemic in Georgia. Pedagogical Research, 5(4). https://doi.org/10.29333/pr/7937

3. Dewi, W. A. F. (2020). Dampak COVID-19 terhadap Implementasi Pembelajaran Daring di Sekolah Dasar. Edukatif: Jurnal Ilmu Pendidikan, 2(1), 55-61. https://doi.org/10.31004/edukatif.v2i1.89

4. Fauzi, I., \& Khusuma, I. H. S. (2020). Teachers' Elementary School in Online Learning of COVID-19 Pandemic 
Conditions. Jurnal Iqra' : Kajian Ilmu Pendidikan, 5(1), 58-70. https://doi.org/10.25217/ji.v5i1.914

5. Gikas, J., \& Grant, M. M. (2013). Mobile computing devices in higher education: Student perspectives on learning with cellphones, smartphones \& social media. Internet and Higher Education, 19, 18-26. https://doi.org/10.1016/j.iheduc.2013.06.002

6. Iftakhar, S. (2016). Google Classroom: What Works and How? Journal of Education and Social Sciences, 3(1), $12-18$.

7. Ihsanuddin. (2020). Fakta Lengkap Kasus Pertama Virus Corona di Indonesia. Kompas.

8. Jere, N. R., Jona, W., \& Lukose, J. M. (2019). Effectiveness of Using WhatsApp for Grade 12 Learners in Teaching Mathematics in South Africa. 2019 IST-Africa Week Conference, IST-Africa 2019, 1-12. https://doi.org/10.23919/ISTAFRICA.2019.8764822

9. Kemendikbud. (2020). Surat Edaran Nomor 4 Tahun 2020 Tentang Pelaksanaan Kebijakan Pendidikan Dalam Masa Darurat Penyebaran COVID.

10. Korucu, A. T., \& Alkan, A. (2011). Differences between m-learning (mobile learning) and e-learning, basic terminology and usage of m-learning in education. Procedia - Social and Behavioral Sciences, 15, 1925-1930. https://doi.org/10.1016/j.sbspro.2011.04.029

11. Kuntarto, E. (2017). Keefektifan Model Pembelajaran Daring Dalam Perkuliahan Bahasa Indonesia di Perguruan tinggi. Journal Indonesian Language Education and Literature, 3(1), 53-65.

12. Lapitan, L. D., Tiangco, C. E., Sumalinog, D. A. G., Sabarillo, N. S., \& Diaz, J. M. (2021). An effective blended online teaching and learning strategy during the COVID-19 pandemic. Education for Chemical Engineers, 35 , 116-131. https://doi.org/10.1016/j.ece.2021.01.012

13. Lestari, P. A. S., \& Gunawan. (2020). The Impact of Covid-19 Pandemic on Learning Implementation of Primary and Secondary School Levels. Indonesian Journal of Elementary and Childhood Education, 1(2), 58-63.

14. Miles, M. B., \& Huberman, A. M. (1994). Qualitative Data Analysis: An Expanded Sourcebook. SAGE.

15. Nakayama, M., Yamamoto, H., \& Santiago, R. (2007). Relationship between learner characteristics and learning performance in hybrid courses among Japanese students. Proceedings of the International Conference on ELearning, ICEL, 2007-Janua(3), 341-349.

16. Nanda, V. K. P. (2019). Social Media in Higher Education: A Framework for Continuous Engagement. International Journal of Information and Communication Technology Education (IJICTE), 15(1), 12.

17. Nuraini, N. L. S., Qihua, S., Venatius, A. S., Slamet, T. I., \& Cholifah, P. S. (2020). Distance Learning Strategy in Covid-19 Pandemic for Primary Schools. Proceeding International Webinar Series - Educational Revolution in Post Covid Era, 2020(April 2020), 107-116.

18. Purwanto, A., Pramono, R., Asbari, M., Hyun, C. C., Budi Santoso, P., Wijayanti, L. M., Putri, R. S., \& Santoso, P. B. (2020). Studi Eksploratif Dampak Pandemi COVID-19 Terhadap Proses Pembelajaran Online di Sekolah Dasar. EduPsyCouns: Journal of Education, Psychology and Counseling, 2(1), 1-12. https://ummaspul.ejournal.id/Edupsycouns/article/view/397

19. Putri, R. S., Purwanto, A., Pramono, R., Asbari, M., Wijayanti, L. M., \& Hyun, C. C. (2020). Impact of the COVID-19 pandemic on online home learning: An explorative study of primary schools in Indonesia. International Journal of Advanced Science and Technology, 29(5), 4809-4818.

20. Rusmiati, A. R., Reza, R., Achmad, S., Syaodih, E., Nurtanto, M., Sultan, A., Riana, A., \& Tambunan, S. (2020). The perceptions of primary school teachers of online learning during the COVID-19 pandemic period: A Case study in Indonesia. Journal of Ethnic and Cultural Studies, 7(2), 90-109.

21. Sahidillah, M. W., \& Miftahurrisqi, P. (2019). Whatsapp sebagai Media Literasi Digital Siswa. Jurnal VARIDIKA, 1(1), 52-57. https://doi.org/10.23917/varidika.v1i1.8904

22. Sari, T., \& Nayir, F. (2020). Challenges in Distance Education During the (Covid-19) Pandemic Period. Qualitative Research in Education, 9(3), 328-360. https://doi.org/10.17583/qre.2020.5872

23. Setiawan, B., \& Iasha, V. (2020). Covid-19 Pandemic: the Influence of Full-Online Learning for Elementary School in Rural Areas. Jpsd, 6(2), 114-123.

24. Smaldino, E. (2012). Instructional Media and Technology for Learning. International Journal of Distributed and Parallel Systems, 3, 8.

25. So, S. (2016). Mobile instant messaging support for teaching and learning in higher education. Internet and Higher Education, 31, 32-42. https://doi.org/10.1016/j.iheduc.2016.06.001

26. Unicef. (2020, March). Spreading facts, not fear, in the fight against Coronavirus.

27. Zaharah, Z., \& Kirilova, G. I. (2020). Impact of Corona Virus Outbreak Towards Teaching and Learning Activities in Indonesia. SALAM: Jurnal Sosial Dan Budaya Syar-I, 7(3). https://doi.org/10.15408/sjsbs.v7i3.15104

28. Zhang, D., Zhao, J. L., Zhou, L., \& Nunamaker, J. F. (2004). Can e-learning replace classroom learning? Communications of the ACM, 47(5), 75-79. https://doi.org/10.1145/986213.986216 